\title{
Optimization of quality indicators of raw milk and dairy products
}

\author{
Tatiana Ananeva*, and Vera Ostroukhova \\ Russian State Agrarian University - Moscow Timiryazev Agricultural Academy, Moscow, Russia
}

\begin{abstract}
Milk is a part of many food products. In the expert assessment of raw material quality, primary attention should be paid to its microbiological safety, since poisoning with dairy products is a common cause of gastrointestinal tract diseases. The experiment was conducted on the basis of the Educational and Production Livestock Complex of the FSBEI HE RSAU - MAA n.a. K.A. Timiryazev (city of Moscow). The purpose of the study is to optimize the quality indicators of raw milk and dairy products. A method of raw milk processing has been studied to reduce the number of potentially dangerous microorganisms in the products produced from it. The fact of changes in organoleptic and physico-chemical parameters under the influence of an electromagnetic field is established; the quantitative and qualitative composition of milk and yogurt microorganisms is assessed. The article describes the issues of ensuring the microbiological safety of raw milk and suggests a method for optimizing the sanitary and hygienic indicators of dairy products, in accordance with the current requirements of regulatory documents.
\end{abstract}

\section{Introduction}

The dairy industry is the most important food processing industry, which has the latest technological devices and equipment designed to ensure the quality and safety of products for the consumer.

Russian processing companies, using the world's advanced experience in milk processing technology, produce a wide range of high-quality and full-value food products.

The incentive for the dynamic development of the milk processing industry is designed to be high requirements for raw milk quality and safety. Milk is able to replace a number of food products in terms of biological and nutritional value, but not every product is able to replace milk.

Focusing on improving the organoleptic, physico-chemical and technological properties of raw materials optimizes the quality indicators of dairy products, the regulatory requirements for which are specified in the regulatory documents.

Improper veterinary and sanitary control, non-optimal technological modes of raw material production, violations of regulations during its processing and storage, potentially contribute to an increase in bacterial contamination and the accumulation of waste products

\footnotetext{
${ }^{*}$ Corresponding author: ananieva@rgau-msha.ru
} 
of microorganisms. A decrease in the sanitary and hygienic characteristics of milk leads to a loss of the quality of dairy products and can cause food toxicoinfections in people. Therefore, microbiological analysis, as an objective method of examining the sanitary quality and technological properties of milk, is intended to be a mandatory point of production quality control of raw materials.

In parallel with the classical methods of raw milk primary processing, innovative technologies are being developed to improve its quality and safety. One of these solutions is the treatment of milk that has not been subjected to preliminary heat treatment with an electromagnetic pulse (EMP) that preserves the $\mathrm{pH}$ and acidity. Microbiological analyses of the samples showed that the magnetic influence reduces the total number of microbes by $25 \%[1]$.

Further research in the field of electromagnetic pulse application can be promising, widely used in food preservation technology, without reducing their quality and providing prolonged storage. The use of an electromagnetic field can minimize the heat treatment of raw materials in the production of dairy products.

The purpose of the experiment is to develop a method for optimizing the quality indicators of raw milk, detailing and specifying the parameters of the electromagnetic pulse to improve the organoleptic, physico-chemical and microbiological parameters of the finished lactic acid product - yogurt.

\section{Materials and methods}

The research was carried out on the livestock of black-and-white cows of the Educational and Production Livestock Complex of the Russian State Agrarian University - MAA named after K.A. Timiryazev (city of Moscow). The animals were kept in the conditions of tethered milk production technology, the age of the experimental livestock was two or three lactation periods.

The material of the experiment was raw bulk milk obtained during the morning milking and not subjected to heat treatment.

In accordance with the requirements of GOST 26809.1-2014 [2], milk samples were taken and the necessary preparation of samples for analysis was carried out.

The organoleptic parameters of milk were evaluated by the criteria of consistency, taste, smell and color, according to the recommendations of GOST 28283-2015 [3]. The milk microbiology was studied no later than two hours after sampling, in accordance with the methodological recommendations of GOST ISO/TS 17728-2017 [4].

In the spring season, the chemical composition of the milk under study was analyzed with a frequency of once a month, including the mass fraction of fat, protein, lactose and dry matter using a quality characteristics analyzer - Bentley 2000. Indicators of thermal stability, density, acidity, as well as the freezing point of raw milk were determined according to generally accepted methods.

Among the sanitary and hygienic indicators of raw milk, the purity group, the content of somatic cells, the residual amount of antibiotics and the species composition of microorganisms were studied once a month with a three-fold repetition. In accordance with the setting of GOST 8218-89 [5], the purity group was determined. To count somatic cells in milk samples, the Somacount 300 analyzer was used, which is based on the cytometric method. The residual amount of antibiotics in the collected milk was recorded by the express test "4SENSOR KIT 060" in accordance with GOST 32219-2013 [6].

The examination of the sanitary quality and microbiology of milk raw materials was carried out on the basis of the requirements of regulatory documents $[7,8]$.

The activity of the electromagnetic pulse (hereinafter referred to as EMP) influence on the quality characteristics of raw milk was analyzed using the laboratory unit described 
below. The unit consisted of the following components: a current pulse generator, a control panel that allows to adjust the output voltage and the duration of the pulse/pause, and a container with a sample placed in it for research. As a control group, milk samples were selected that were not subjected to pretreatment by pulse. For the experimental group, the following exposure parameters were used: EMR duration $19.28 \mathrm{~ms}$ with a pause of 19.64 $\mathrm{ms}$. The output voltage was $22 \mathrm{~V}$, and the sample processing time was 20 minutes.

Yogurt was produced in the traditional way, the technological process included the following stages: acceptance and preparation of milk, pasteurization and cooling, culture introduction, mixing and fermentation of the mixture [9].

The milk was pasteurized to $90^{\circ} \mathrm{C}$, then cooled to $43 \pm 2^{\circ} \mathrm{C}$ and a culture containing thermophilic milk streptococci and Lactobacillus bulgaricus was added. The resulting culture was added to the raw milk and placed in a thermostat for 8 hours at a temperature of $41{ }^{\circ} \mathrm{C}$. The volume of the introduced culture was $10 \%$ of the total volume.

\section{Results and discussion}

Based on the results of a comprehensive evaluation of raw milk, it was found that the electromagnetic pulse generator did not significantly affect the organoleptic characteristics (Table 1). The consistency uniformity was characteristic of both the control and the experimental group, no sediment and flakes were detected, the samples had a milky white color and the smell inherent in natural milk.

Table 1. Organoleptic parameters of raw milk.

\begin{tabular}{|c|c|c|}
\hline Indicator & Control & Experiment \\
\hline Consistency & $\begin{array}{c}\text { Homogeneous liquid without } \\
\text { sediment and flakes }\end{array}$ & $\begin{array}{c}\text { Homogeneous liquid without sediment } \\
\text { and flakes }\end{array}$ \\
\hline $\begin{array}{c}\text { Taste and } \\
\text { smell }\end{array}$ & $\begin{array}{c}\text { Clean, without foreign odors and } \\
\text { tastes that are not characteristic of } \\
\text { fresh milk }\end{array}$ & $\begin{array}{c}\text { Clean, without foreign odors and tastes } \\
\text { that are not characteristic of fresh milk }\end{array}$ \\
\hline Colour & From white to light cream & From white to light cream \\
\hline
\end{tabular}

The milk of the control and experimental samples differed slightly in quality characteristics (Table 2). The mass fraction of fat in the samples of both groups was 3.60 $\%$, protein - ranged from 3.30 to $3.39 \%$, lactose - ranged from 4.58 to $4.62 \%$. The maximum differences were noted in the dry matter content, the mass fraction of which in the experimental samples was $12.70 \%$. Thus, the main indicators of the nutritional value of milk did not change during electromagnetic processing.

Table 2. Physical and chemical parameters of raw milk.

\begin{tabular}{|l|c|c|}
\hline \multicolumn{1}{|c|}{ Indicator } & Control & Experiment \\
\hline Mass fraction of dry matter, $\%$ & $12.54 \pm 0.02$ & $12.70 \pm 0.05$ \\
\hline Mass fraction of fat, $\%$ & $3.60 \pm 0.15$ & $3.60 \pm 0.13$ \\
\hline Mass fraction of protein, $\%$ & $3.30 \pm 0.04$ & $3.39 \pm 0.02$ \\
\hline Mass fraction of lactose, $\%$ & $4.58 \pm 0.34$ & $4.62 \pm 0.33$ \\
\hline Thermal stability group & II & II \\
\hline Density, $\mathrm{kg} / \mathrm{m}^{3}$ & $1026.30 \pm 0.07$ & $1029.80 \pm 0.05$ \\
\hline Acidity, ${ }^{\circ} \mathrm{T}$ & $16.09 \pm 0.09$ & $16.12 \pm 0.12$ \\
\hline Freezing point, ${ }^{\circ} \mathrm{C}$ & $-0.526 \pm 0.053$ & $-0.522 \pm 0.061$ \\
\hline
\end{tabular}

The absence of a negative effect of the electromagnetic field on the physical and chemical properties of the raw material was established. Density and acidity indicators confirm the naturalness and freshness of the tested milk samples. The freezing point eliminates the possibility of falsification of samples and identifies them as raw cow's milk. 
Sanitary and hygienic indicators that do not meet the requirements of regulatory documents can reduce the quality and safety of raw materials and, accordingly, dairy products. Milk samples are assigned to the I group of purity (Table 3).

Table 3. Sanitary and hygienic indicators of raw milk.

\begin{tabular}{|l|c|c|}
\hline \multicolumn{1}{|c|}{ Indicator } & Control & Experiment \\
\hline Purity group & $\mathrm{I}$ & $\mathrm{I}$ \\
\hline Somatic cell content, thousand/cm $\mathrm{cm}^{3}$ & $143.5 \pm 4.22$ & $147.1 \pm 3.20$ \\
\hline $\begin{array}{c}\text { Potentially dangerous substances - antibiotics: } \\
\text { levomycetin } \\
\text { (chloramphenicol) } \\
\text { tetracycline group } \\
\text { streptomycin } \\
\text { penicillin }\end{array}$ & Not found & Not found \\
\hline
\end{tabular}

The content of somatic cells in the studied samples suggests that the milk was obtained from clinically healthy cows and meets the standards specified in the regulatory documents $[7,8]$.

According to Table 3, it can be seen that the tested milk fully meets the requirements of TR TS 033/2013 "On the safety of milk and dairy products" for the residual amount of antibiotics, which is confirmed by the absence of pollutants and indicates the quality and safety of raw materials [8].

In the experimental samples, after EMR treatment, a decrease in the growth rate of microorganisms, including QMA\&OAMO, yeast and mold, was noted. Bacteria of the Staphylococcus aureus and Escherichia coli groups were not found in the studied milk samples. The electromagnetic field had a negligible effect on the number of lactic acid microorganisms (Table 4).

Table 4. Microbiological indicators of raw milk.

\begin{tabular}{|c|c|c|}
\hline Indicator & Control & Experiment \\
\hline QMA\&OAMO, $\mathrm{CFU} / \mathrm{cm}^{3}$ & $6.1 \times 10^{5}$ & $5.7 \times 10^{4}$ \\
\hline Lactic acid microorganisms, $\mathrm{CFU} / \mathrm{cm}^{3}$ & $2.1 \times 10^{2}$ & $1.9 \times 10^{2}$ \\
\hline Staphylococcus aureus, $\mathrm{CFU} / \mathrm{cm}^{3}$ & Not found & Not found \\
\hline Escherichia coli, CFU $/ \mathrm{cm}^{3}$ & Not found & Not found \\
\hline Yeast, $\mathrm{CFU} / \mathrm{cm}^{3}$ & $9.2 \times 10^{3}$ & $4.5 \times 10^{3}$ \\
\hline Yeast, CFU $/ \mathrm{cm}^{3}$ & $4.7 \times 10^{1}$ & $3.9 \times 10^{1}$ \\
\hline
\end{tabular}

Yogurt is a fermented milk product obtained from milk and a mixture of starter cultures (Lactobacillus bulgaricus + thermophilic streptococci). At the end of the fermentation process, an organoleptic evaluation of the product quality was performed (Table 5).

Table 5. Organoleptic characteristics of yogurt.

\begin{tabular}{|c|c|c|}
\hline Indicator & Control & Experiment \\
\hline $\begin{array}{c}\text { Appearance and } \\
\text { consistency }\end{array}$ & $\begin{array}{c}\text { Homogeneous, with an undisturbed } \\
\text { clot, moderately viscous with a } \\
\text { small amount of separated whey }\end{array}$ & $\begin{array}{c}\text { Homogeneous, with an undisturbed } \\
\text { clot, moderately viscous with a small } \\
\text { amount of separated whey }\end{array}$ \\
\hline Taste and smell & $\begin{array}{c}\text { Clean, fermented milk without } \\
\text { foreign odors and tastes }\end{array}$ & $\begin{array}{c}\text { Clean, fermented milk without foreign } \\
\text { odors and tastes }\end{array}$ \\
\hline Color & Milky white, without inclusions & Milky white, without inclusions \\
\hline
\end{tabular}

The organoleptic parameters of the yogurt of the control and experimental samples did not have significant differences. The appearance and consistency of the developed lactic acid product is homogeneous, moderately viscous, with undisturbed clot, milky-white in color. There is a small amount of separated whey on the yogurt surface. The smell is fermented milk without foreign impurities. 
The results of the tasting evaluation of the product are presented in Table 6 .

Table 6. Tasting evaluation of organoleptic parameters.

\begin{tabular}{|c|c|c|}
\hline Indicator & Control & Experiment \\
\hline Appearance and consistency & 4 & 4 \\
\hline Taste and smell & 5 & 5 \\
\hline Colour & 5 & 5 \\
\hline
\end{tabular}

The physical and chemical characteristics of the product produced from raw milk exposed to electromagnetic radiation and the control sample differed slightly, which demonstrates the absence of a negative effect of EMR on the chemical composition and acidity of yogurt (Table 7).

Table 7. Physical and chemical parameters of yogurt.

\begin{tabular}{|c|c|c|}
\hline Indicator & Control & Experiment \\
\hline Mass fraction of fat, \% & $4.23 \pm 0.03$ & $4.29 \pm 0.05$ \\
\hline Mass fraction of protein, \% & $3.26 \pm 0.02$ & $3.34 \pm 0.02$ \\
\hline Acidity, ${ }^{\circ} \mathrm{T}$ & $115 \pm 1.5$ & $114 \pm 1.2$ \\
\hline
\end{tabular}

The control sample contained mesophilic aerobic and facultatively anaerobic microorganisms in an amount less than yogurt produced by using an electromagnetic pulse for raw milk processing (Table 8). Of the total QMA\&OAMO in the experimental sample, the overwhelming number of microorganisms was lactic acid flora, which allows to assume the objective influence of EMR stimulating their growth and development. Pathogenic and opportunistic microorganisms, as well as yeast and mold were not detected.

Table 8. Microbiological parameters of yogurt.

\begin{tabular}{|c|c|c|}
\hline Indicator & Control & Experiment \\
\hline QMA\&OAMO, CFU $/ \mathrm{cm}^{3}$ & $3.9 \pm 10^{8}$ & $4.3 \pm 10^{8}$ \\
\hline Lactic acid microorganisms, $\mathrm{CFU} / \mathrm{cm}^{3}$ & $3.7 \pm 10^{8}$ & $4.1 \pm 10^{8}$ \\
\hline Staphylococcus aureus, CFU/ $/ \mathrm{cm}^{3}$ & Not found & Not found \\
\hline Escherichia coli, CFU $/ \mathrm{cm}^{3}$ & Not found & Not found \\
\hline Yeast and mold, CFU/ $\mathrm{cm}^{3}$ & Not found & Not found \\
\hline
\end{tabular}

\section{Results and discussion}

During the experiment, there was no negative effect of electromagnetic radiation on the organoleptic and physical and chemical parameters of raw milk and yogurt produced from it. The EMR effect on the minimization of QMA\&OAMO and the content of spoilage microorganisms in the raw materials was established. Milk and lactic acid product of the control and experimental groups met the standards established by the Technical Regulations of the EAEU "On the safety of milk and dairy products "(TR TS 033/2013), the Technical Regulations of the EAEU "On the safety of food products "(TR TS 021/2011) and GOST 31981-2013 "Yoghurts. General technical conditions" [7-9]. The sanitary and hygienic parameters of milk can be optimized by using an electromagnetic pulse generator, which will lead to an improvement in the quality and safety of raw materials used in the production of dairy products $[10,11]$.

\section{References}

1. Hanen Ben Hassen, Anis Elaoud, Ismail Trabelsi, International Journal of Advance Industrial Engineering, 5(4), 200-204, (2017) 
2. GOST 26809.1-2014 Milk and dairy products. Acceptance rules, sampling methods, and sample preparation for analysis. Part 1. Milk, dairy, dairy compound and milk-containing products (as amended) http://docs.cntd.ru/document/1200115726

3. GOST 28283-2015 Cow's milk. Method of organoleptic evaluation of taste and smell (with correction) http://docs.cntd.ru/document/1200124738

4. GOST ISO/TS 17728-2017 Microbiology of the food chain. Methods of sampling for food products and feed for microbiological analysis http://docs.cntd.ru/document/1200157424

5. GOST 8218-89 Milk. Method for determining purity http://docs.cntd.ru/document/1200021604

6. GOST 32219-2013 Milk and dairy products. Immunoassay methods for determining the presence of antibiotics (with Change No. 1) https://beta.docs.cntd.ru/document/1200107340

7. TR TS 021/2011 Technical Regulations of the Customs Union "On food safety" (as amended on August 8, 2019) http://docs.cntd.ru/document/902320560

8. TR TS 033/2013 Technical Regulations of the Customs Union "On the safety of milk and dairy products" (as amended on July 10, 2020) http://docs.cntd.ru/document/499050562

9. GOST 31981-2013 "Yoghurts. General technical conditions" https://beta.docs.cntd.ru/document/1200107778

10. T. Ananeva, V. Ostroukhova, E. Vasilyeva, InEngineering for Rural Development. Latvia University of Agriculture, 17, 90-96 (2018)

11. T.V. Ananeva, V.I. Ostroukhova, Proceedings of the Timiryazev Agricultural Academy, 2, 60-71 (2019) 